\title{
Coping with Innovative technology ${ }^{1}$ : Albert Borgmann on how does technology change learning and teaching in formal and informal education ${ }^{2}$.
}

\author{
By \\ Arun Kumar Tripathi \\ Department of Philosophy of Technology \\ Institute for Philosophy \\ Dresden University of Technology \\ Germany
}

Technology has captured the character of contemporary culture. It reminds us of the artefacts and procedures that distinguish our time. Computing will become more pervasive, but not to extent it s visionaries think. For one thing, as their examples show, the benefits are for the most part crashingly banal. For another, people will want to continue to appropriate their world in a knowing and competent way. Pearl in an oyster is not a satisfying condition for humans. The disappearance of the information highway was, sadly, entirely foreseeable. The phenomenon is the converse of the point above. We have become used to appropriate our world through consumption rather than excellence. Informational citizenship would be a kind of excellence. Consumption is procured by business. We are divided in our relation to reality, aspiring to excellence and finding ourselves to be consumers. The only truly different ambivalence in favour of excellence. The future will judge us not by our potentials but by what we have made of them, not so much far. It is great that we have ability to reach out and touch people all around the world. I don't pretend to know what the end results will be, but it is exciting to be living and working in a world, where the potential to somehow touch

\footnotetext{
${ }^{1}$ The paper is dedicated to Professor Albert Borgmann and his works on philosophy of society \& culture and philosophy of technology, over the years on which Borgmann has emphasized the contemporary issues of Philosophy \& Ethics in Academe in several perspectives.

${ }^{2}$ Part of this article with title Digital Resources in Education is published in Ubiquity: An ACM IT Magazine and Forum at http://www.acm.org/ubiquity/views/a_tripathi_3.html
} 
each of the six billion people of the world exists. I am acutely aware of the inequities and that at least a fourth of the world's population does not have access to a telephone or for that matter even seen a telephone. In the 1890s the most optimistic futurists thought that there might be one telephone in every USA village. It was inconceivable that the telephone companies would be advertising "family cell phone." What the next century will bring is hard to guess. Ray Kurzweil believes by 2020 we can have Mind Prints, i.e. download our brains into computers. Other futurists tell us it is not inconceivable that we will have direct brain to machine communications. It's a wonderful future world. The challenge is for us to make the best of it and not squander it.

In particular, the observation of Borgmann about the design has some interesting implications: Our contact with reality has been attenuated to the pushing of buttons and the turning of handles. The results are guaranteed by machinery that is not of our design and often beyond our understanding. Hence the feelings of liberation and enrichment quickly fade; the new devices lose their glamour and meld into the conspicuous periphery of normalcy; boredom replaces exhilaration. ${ }^{3}$

In the introduction of his book Holding On to Reality (published by the University of Chicago Press) -Albert Borgmann examines information vs. Reality. He then makes several distinctions which serve to organize the book into three separate but related parts:

Natural Information: Information about Reality

Cultural Information: Information for Reality

Technological Information: Information as Reality

So far, as the current Age of Information is concerned, Holding On to Reality has some truly profound implications which are best suggested by a series of questions:

\footnotetext{
${ }^{3}$ Albert Borgmann, Technology and the Character of Contemporary Life, 1984, P. 140.
} 
What is the nature of information?

Where does it exist? (How is it organized?)

How can it be obtained?

How does information differ from knowledge?

What is the relationship between them?

To what extent does information give structure to reality?

To what extent does information reflect reality?

To what extent is information wholly unrelated to the natural world? and How is information related to the arts and sciences (to language, music, mathematics, and biology)?

Scholar and philosopher Albert Borgmann wants us to pry ourselves free and grasp actual reality. With it s uniqueness and great in weight and "burden” it will command our serious attention. Virtual reality merely requires our fast-fingered manipulation. The flood of information today threatens to overflow, suffocate and even obliterate actual reality, says the University of Montana philosophy professor Albert Borgmann. The "lightness" of technological information seems bent on overcoming the "moral gravity" and "material density" that real things naturally possess and that demand our mindful engagement. Albert Borgmann is not asking us to abandon technological information. But he is calling us (giving us a warning-play safe) to link it effectively to "things and practices" that provide for our material and spiritual well-being. In a discussion, Albert Borgmann and Donna Haraway are brought into conversation to examine the relationship between technology and temporal ambiguity and, ultimately, the question of the moral efficacy of ambiguity. The examination is guided by examples of virtual reality technology drawn from Borgmann and Katherine Hayles. Both Borgmann's and Haraway's accounts of technology serve to elucidate experiences of temporal ambiguity and to clarify questions of commitment. However, it is good to concludes that, in temporal terms, Haraway's desire, through the metaphor of the cyborg, to imagine a world that can be otherwise, serves, among others things, to consign us to a form of cyborg narcissism which betrays our commitments to 
ending injustices against humans and other beings. Borgmann, on the other hand, in his proposals ${ }^{4}$ for the reform of technology through focal things and practices, does not take questions of gender and cross-cultural differences into account sufficiently, and so fails to go far enough in rethinking social change. Ultimately, Borgmann's and Haraway's accounts serve as correctives to one another, but both would be strengthened by taking questions of individual and collective experiences of temporality more seriously.

As computers become smaller, cheaper, and more mobile, people expand the ways in which they interact with information. Information that previously could only be accessed by a trip to the library can now be found on everyone's desktop, and before long will be on their cell phone screens or on the wall next to them. Although there has been much promotion of the wonders of ubiquitous information, there are also many problems. Information on the go, no longer has the contextual backing that it did, within information-providing institutions. Interfaces that worked well on paper don't transfer easily to the screen, and less so, to the mini-screen. Research in human-computer interaction is moving away from desktop window-based interfaces to consider this larger picture.

Human-Computer Interaction (HCI) is concerned with the design, implementation and evaluation of interactive computer-based systems, as well as with the multi-disciplinary study of various issues affecting this interaction. The aim of HCI is to ensure the safety, utility, effectiveness, efficiency, accessibility and usability of such systems. In recent years, HCI has attracted considerable attention by the academic and research communities, as well as by the Information Society Technologies industry. The on-going paradigm shift towards a knowledge-intensive Information Society has brought about radical

\footnotetext{
${ }^{4}$ Albert Borgmann coping with Innovation and Experiential connection to the Nature, engaging with reality \& temporal ambiguity and Technology and Good Life?.
} 
changes in the way people work and interact with each other and with information. Computer-mediated human activities undergo fundamental changes and new ones appear continuously, as new, intelligent, distributed, and highly interactive technological environments emerge, making available concurrent access to heterogeneous information sources and interpersonal communication. The progressive fusion of existing and emerging technologies is transforming the computer from a specialist's device into an information appliance. This dynamic evolution is characterized by several dimensions of diversity that are intrinsic to the Information Society. These become evident when considering the broad range of user characteristics, the changing nature of human activities, the variety of contexts of use, the increasing availability and diversification of information, knowledge sources and services, the proliferation of diverse technological platforms, etc.

HCI plays a critical role in the context of the emerging Information Society, as citizens experience technology through their contact with the user interfaces of interactive products, applications and services. Therefore, it is important to ensure that user interfaces provide access and quality in use to all potential users, in all possible of contexts of use, and through a variety of technological platforms. The field of HCI is now experiencing new challenges. New perspectives, trends and insights enriching the design, implementation and evaluation of interactive software, necessitating new multidisciplinary and collaborative efforts.

In Culture of Technology, Borgmann argues on consumption, community and celebration. The character of contemporary culture is best captured, I believe by the term technology. It reminds us of the artefacts and procedures that distinguish our time. And, on consumption Borgmann said "Consumption is the adversary of community. In a philosophical sense, consumption is the unencumbered of glamorous commodities.” 
Albert Borgmann provides in Technology and the Character of Contemporary Life ${ }^{5}$ a unique way of conceiving of the inherent limitations of technology in the betterment of life by an explication of the 'device paradigm'. According to Professor Borgmann, the promise of technology is improving the quality of life has turned out to be inherently limited, and that technology must be seen for what it really is and what it can offer whilst distinguishing it from 'focal things and practices' which can provide the requirements necessary to achieve fulfilment in life.

\section{II}

How does technology change learning and teaching in formal and informal education?

It seems that the days of the Socratic teacher are fast fading. The digital world gives everyone an opportunity to find his or her own expert, not necessarily in the classroom. The Internet and other digital resources provide students and teachers with the means to reach out to the world and extract the information that they find most interesting, whatever it may be. In the classroom there are many things that the students know more about their teachers, simply because the students can do research that was once tedious and required many trips to the library, yet now only needs a few clicks of the mouse. I believe that the teacher's role will eventually be that of a facilitator, giving hints and directions on how to find knowledge rather than dishing it out on a silver plate. Of course, some of the good teachers do this already, and will find it easy to use technology to expand their resources.

Philosopher Albert Borgmann reminds us, the contemporary use of the word information emerged only in the middle of the twentieth century. Prior to this information as a concept lived an obscure bookish life. With the rise of mechanistic and reductionistic explanations of the function of

\footnotetext{
${ }^{5}$ Published in 1984 -in short it is called as TCCL.
} 
the world as promulgated by physical, natural and social scientists, it became necessary to provide order to the world, to get "from atoms and molecules to patterns of landmarks that would order and guide our lives. (Borgmann 1999, p. 10).

"While the real world holds misery and grace, the hyper-real universe contains only news, challenges that demand one's reaction. And while in reality one may be defeated or redeemed, in hyper-reality one can only win or lose. In the real world one may earn affection and gratitude, in the hyper-real framework there are only prizes and acclaim." (Albert Borgmann, Crossing the Post-modern Divide Chicago: University of Chicago Press, 1992, p. 99)

Borgmann's monumental recent study of information and technology (1999) ${ }^{6}$ builds on his earlier theory of technology - the device paradigm. The device paradigm explains that technology is not really manifest in things-in-themselves, but in the distinctive patterns created by the interactions between people and devices. Devices are most appropriate when they are embedded in a rich social context that has sufficient strength to appropriate the device to socially-intended uses, instead of device-driven uses.

Philosopher Albert Borgmann points out the problem with distance education:

"Billions of dollars are dedicated to educational hardware and software, but next to nothing is spent to get reliable information on the costs and benefits of the expenditures.... The rhetoric of recasting education within the framework of information technology is well attuned to the promise of technology and, in fact, to the implementation of that promise. The disburdenment from the constraints of time, place, and the decisions of other people is the unique accomplishment of modern technology and finds its everyday realization in consumption. Supported by the machinery of technology, consumption is the unencumbered enjoyment

\footnotetext{
${ }^{6}$ Borgmann, Albert. 1999. Holding On to Reality. University of Chicago Press.
} 
of whatever one pleases. The pleasures of consumption require no effort and hence no discipline."(Albert Borgmann, Holding On to Reality: The Nature of Information at the Turn of Millennium, Chicago: The University of Chicago Press, p. 207.)

Albert Borgmann on Holding On to Reality and Plato on letter, writing and memory

In his dialogue Phaedrus, Plato recounts the story of the invention of writing, which he attributes to the Egyptian god Theuth. At the heart of Plato's qualms about the written word was recognition that, in modern parlance, this was a major step toward the virtualization of knowledge. For Plato, abstract symbols on a page were a retreat from engagement with "reality." Like Plato, Albert Borgmann reminds us loss of human knowledge and its replacement by the virtualization of knowledge. Regents Philosopher Borgmann also reminds us that whatever the reality of our time, we need "a balance of signs and things" in our lives.

On the issue of language Albert Borgmann writes... "Plato furthermore thought that the analysis of language into sounds or letters reflected the reducibility of reality into elements. "Element," in fact, is a word he uses for the ultimate constituents of both language and reality. What happens to the meaning of language and reality when they are brought down to their elementary levels? Plato's boldest answer was to the effect that meaning is the same as composition and that therefore objects are devoid of composition, that is, the irreducible elements, have no meaning."

If there is a reassuring reply to the apprehension that the meaning of reality is in jeopardy unless,it too goes all the way down, the answer must lie in the demonstration of how synthesizing meaningless elements into compounds reconstitutes meaning. Plato, inspired by the school of Pythagoras tried to provide such a proof, proposing that from two kinds of right-angled triangles we can construct the regular solids-the tetrahedron, the cube, etc. Working his way up to ordinary reality, Plato 
tried to show how all things, living and are not composed of combinations of these elements. To the modern audience, Plato's attempt at deriving the florescence and abundance of reality from such spare components seems fanciful and arbitrary and casts doubt on the very claim that a meaningful world is constructible from meaningless elements.

Human eloquence, of course, is the most articulate and intricate.

But the dream of discovering a thoroughly lawful structure in spoken and, a fortiori, written language was powerful in Plato and has remained so to this day. In the dialogue Cratylus, Plato has Socrates put the guiding conviction is thus : "For the ancients gave language its existing composite character; and if, we are to examine all these matters with scientific ability, must take it to pieces as they put it together and see whether the words, both the earliest and the later, are given systematically or not; for if they are strung together at hap-hazard, it is a poor, unmethodical performance, my dear Hermgenes.” (See, Albert Borgmann: Holding On to Reality: The Nature of Information at the Turn of the Millennium for an insightful demonstration on the human eloquence).

Information theory has never been able to uncover or forge the link between structure of language and structure of reality. Modern information technology, however, has succeeded in devising a kind of equivalence between information and reality. Plato toyed with this project, considering words where the quality of sounds seems to match the quality of the things they refer to. In the end, Plato recognized that contingency and convention, the apparent antagonists of structure and regularity, most often provide the answer, if in fact they constitute an answer, as to why a certain word refers to a certain thing.

Plato was among those early philosophers who tried to subordinate contingency to structure. The leading idea was to reduce what strikes us 
as marvellous or mysterious to an underlying simplicity and lawfulness. In the Timaeus, Plato tried to build up the world of direct experience from the regular solids that in turn, he thought, were constructed from two kinds of triangles.

While Plato surely was wrong in fearing that writing would undermine indirect knowledge, that is, the comprehension via signs of matters that are distant in space or time, he rightly saw that detached information can be the adversary of direct knowledge - the acknowledgment of thoughtful and eloquent persons in their immediate presence. Philosophy, as Plato saw it, comes truly alive only when living persons are engaged in an actual dialogue.

Writing, however, not only has the capacity of natural information in a heightened version, it has in addition a very nearly novel power. It is a power that Plato, fearful for the welfare of knowledge, was unable to acknowledge. In his efforts to secure the dignity of knowledge, he sought to restrict letters to the status of reminders, purely mnemonic signs conveying merely retrospective contents. Only a fool would think, he said, "that written words are of any use except to remind him who knows the matter about which they are written."

Young men with books were regarded as ridiculous figures in Athenian comedy. Phaedrus in Plato's dialogue, very nearly is one of them. He is both enamoured with a copy of the speech he carries around and ashamed of displaying it when he runs into Socrates. More generally, Plato held that writing is not for serious matters. Even laws, once committed to writing, suffer a loss of weight and seriousness. Plato recognized that, writing compacts the large and living structure of natural information and feared that detached parcels of written information, easily acquired, would take the place of genuine wisdom, arduously earned. Writing, Plato thought, would promote both vanity and stupidity. 
To have information is to have (indirect) knowledge. But once writing appeared on the cultural scene, it was possible to have information, in the sense of owning a book, without having knowledge, that is, without having read it. Plato thought the ambiguity was insidious in bestowing the prestige of knowledge on people who owned information without having absorbed it.

Along the similar lines of thoughts of Albert Borgman, Hubert Dreyfus also in his latest book On the Internet: Thinking in Action, spells out the Plato's thought on writing, as he comments...

"After all, in the 'Phaedo' Plato famously objected to the introduction of writing as opposed to speech, because, as pointed out, writing reduces the richness of communication since it makes it impossible to read the speaker's tone and bodily posture. Furthermore, Plato saw that, if assignments could be made at a distance, they would not be as binding as agreements sealed by the spoken word. Plato also thought that people would loose their ability to remember important events."

Of course, all seem to be true, but Plato couldn't foresee that, thanks to writing, we would gain a wider range of communication, new ways of making contracts at a distance, and a whole new cultural memory. If Plato could have thought along these lines, he might well have had a more positive view of the trade-offs involved.

Professor Borgman's treatment of the co-evolution of information infrastructures in a global society seem to refine the position that distant education finds itself as traditional academia struggles between revolutionary and evolutionary adopters. Some of the struggles we've seen over the years in our society can surely be tracked to the variations of early and late technology adopters, experience, and adaptability. Within any organizational structure there will most assuredly be a normal distribution of interests, concerns, and connectivity 
(psychological, physiological, and technological) that adds flavour as well as guile to communications.

Where technological resembles cultural information, differences between reality and cyberspace are less stark. The lack of repleteness and continuity gives technological information a special sort of under determination. The lack of continuity gives technological information a peculiar kind of brittleness. Information in cyberspace fails to have the suppleness and life that the semantic plenum of reality supplies to natural and cultural information and to the presence of real things and persons. (Albert Borgmann, Information, Nearness and Farness, in The Robot in the Garden: Tele-robotics and Tele-epistemology in the Age of the Internet, ed. Ken Goldberg.)

III

Promises of Technology

Is the promise of technology real this time? Thomas Edison and many others thought that motion pictures would change forever the role of the teacher. Radio was heralded in the late 1920s and 1930s as the saviour of our education system. During World War II Disney Studios developed animated learning systems designed to teach very specific tasks. After World War II overhead projectors and audio filmstrips were to become the meat and potatoes of learning resources. Television allowed one good teacher could reach the world. As a matter of fact, these innovations not only provided interesting lessons, but people actually learned from them. They have all proven to be effective in the teaching process.

However, even with their record of success they have not significantly changed the patterns of learning and teaching now present in most schools around the world. The effective measures of educational innovations are 1) Does the innovation increase the master skills of the 
learner? 2) Can the same level of learning be accomplished in a shorter period of time? And 3) Can a teacher teach more students to the same level of accomplishments?

\section{Borgmann $^{7}$ coping with Don Ihde}

In this section, I will undertake Dreyfus's terminology Coping ${ }^{8}$ to compare Montana philosopher Professor Borgmann with Don Ihde. Coping is the Dreyfus's interpretation of Heidegger's use of Coping with technological developments and instrumentation with relation to the world ${ }^{9}$.

Borgmann discuss broadly the questions: How can one experience oneself as an integral part of nature -- not at a conceptual level, but as an actual experience? And how have we lost the experience of our connection with nature?; in his Trilogy ${ }^{10}$ based on Philosophy of Society and Culture and Technology and Ethics.

Borgmann's thesis is that as we increasingly take up with the world through our work, leisure activities and family time, in a technological manner, our capacities as human beings atrophy and our experiences of the world are diminished. His analysis is much richer and insightful than I can convey. He welcomes the expansion of technologies that ease human suffering, eradicate disease and lift the drudgery of skill less

\footnotetext{
${ }^{7}$ Significant study of Borgmann's philosophy of technology as the rule of the device is done by Drew Leder (Philosophy Today, Spring 1998, pp. 17-30).

${ }^{8}$ This is best discussed in chapters Coping and Its Contrasts, Coping with Others with Folk Psychology, Practices, Practical Holism, and Background Practices, Context and Cognitive Science, Grasping at Straws: Motor Intentionality and the Cognitive Science of Skilled Behavior, Semiartificial Intelligence of the $2^{\text {nd }}$ Vol. of Heidegger, Coping, and Cognitive Science - Essays in Honor of Hubert L. Dreyfus (eds.) Mark Wrathall and Jeff Malpas.

${ }^{9}$ Martin Heidegger (In-der-Welt-Sein) and Maurice Merleau-Ponty (Zu-der-Welt-Sein) attempted each in his own way, to work out an account of human Being-In-the-World through which the untenable idealistic conclusions would be overcome, but both of them failed at critical junctures.

${ }^{10}$ Technology and the Character of Contemporary Life: A Philosophical Inquiry. Chicago: University of Chicago Press, 1984; 5th printing 1997.

Crossing the Postmodern Divide. Chicago: University of Chicago Press, 1992; 5th printing 1998. Chinese translation 2003.

Holding On to Reality: The Nature of Information at the Turn of the Millennium. Chicago: University of Chicago Press, 1999.
} 
burdensome labour from workers. He's also interested in technology that sharpens human experiences of the world such as new materials for musical instruments. There's no list of appropriate or inappropriate technologies. Instead, he arms the reader with a set of concepts that give one the eyes to see what is gained and what is lost when one opts to jog on a treadmill in one's living room rather than being a moving body through a landscape; reckoning with the wind, the inclines; the riches and challenges associated with the particular season.

While doing the review of Ihde's Technology and the Lifeworld: From Garden to Earth Albert Borgmann precisely put "..there is the background relation between humans and technology where a technology, such as air conditioning, has receded into the inconspicuous normalcy of daily life. Ihde's tools properly occupy a pivotal position in his latest work, namely, the very middle of Technology and Lifeworld." (pp. 340) $)^{11}$

Scholarly professor Albert Borgmann wants us to pry ourselves free and grasp actual reality. With its uniqueness, and great in weight and 'burden' it will command our serious attention. On the other side, Virtual Reality merely requires our fast-fingered manipulation. Plausibly, Professor Borgmann argues that, the flood of Information today threatens to overflow, suffocate and even obliterate actual reality.

In “Focal Things and Practices," Borgmann develops Heidegger's analysis by specifying in greater detail what it would mean to launch a "reform of technology.” Borgmann's key distinction is between "things" and "devices." To encounter a thing is to engage it fully and to participate in its "world" - all of the social dimensions of using and experiencing something. A device is merely an instrument for producing a commodity and what the device is for. The device, in principle functions inconspicuously by disburdening us and making a commodity available. Thus, the "promise of modern technology" Borgmann

\footnotetext{
${ }^{11}$ Research in Philosophy and Technology, 13 (1993).
} 
explains is that the use of devices will free us from the misery and work imposed on us by nature and social pressures, and in return will make our lives better by liberating and enriching our experience. However, Borgmann points out that technology have failed to live up to its promise of liberation, because it is silent as to the ends, purposes, and goods that we desire. Like Heidegger Borgmann invites us to see through the pervasiveness and self-reinforcing patterns of technology. But he moves beyond Heidegger - by setting up an original voice Borgmann pleads, to reform technology, we need to revive focal things and focal practices.

In a philosophical sense, consumption is the unencumbered use of glamorous commodities. Borgmann provides in "Technology and the Character of Contemporary Life" [3] a unique way of conceiving of the inherent limitations of technology for the betterment of life by an explication of the "device paradigm." According to Borgmann, the promise of technology for improving the quality of life has turned out to be inherently limited, and that technology must be seen for what it really is and what it can offer while distinguishing it from "focal things and practices" that can provide the requirements necessary to achieve fulfilment in life. Technology ${ }^{12}$ is the kind of life in which enlightenment has been shaped by a promise of liberty and prosperity and taken on a peculiar and pervasive pattern is dominant, can be explicated through the Device Paradigm.

"Philosophers of technology tend not to celebrate technological achievements, because they get celebrated all the time", says Albert Borgmann by emphasizing the problem of how to tame the technological development. Borgmann further elaborates, "Philosophers point out the liabilities, what happens when technology moves beyond lifting genuine burdens and starts freeing us from burdens that we should not want to be rid of."

\footnotetext{
${ }^{12}$ Reply to the Symposium on Albert Borgmann in Paul Durbin (ed.) Technology and Contemporary Life (P.34).
} 
Albert Borgmann further argues, "A crucial feature of a technological device is that it makes something available to us in a comfortable way. You don't have to work for it..” on how technology shape a way of life. The main concerns of Borgmann is thus: How do we gather technological devices together into the good life? Nothing by itself makes a better life. For Albert Borgmann, philosophy is a way of taking up the questions that reside at the center of everyday life, esp. questions that are urgent but often inarticulate. The philosophy of technology, which has been the principal focus of his work since the mid-1970s, is about bringing to light and calling into question the technological shape and character of everyday life.

The first book published in the pragmatic philosophy of technology series, Larry Hickman's John Dewey's Pragmatic Technology (1990), shows that Ihde was not interested, in the series, in pushing his own phenomenological approach to philosophy of technology, but is open to a variety of approaches ${ }^{13}$. Ihde's own approach does show up in his later books, Existential Technics (1983), Consequences of Phenomenology (1986), and Technology and the Lifeworld: From Garden to Earth (1990),even in his Philosophy of Technology: An Introduction (1993), though that textbook does present other views. In general, one can say that Ihde's development is a matter of greater depth and clarity in his phenomenological analysis, though Technology and the Lifeworld gives more than a passing nod to the centrality of environmental concerns.

Don Ihde (1979, 1983, 1990, 1993), who is perhaps next only to Mitcham - and possibly Albert Borgmann, to be mentioned in a moment -, has been widely praised by SPT members. His appearances at SPT meetings are only a tiny fraction of the appearances Ihde makes and the talks he gives all over the world. About Ihde, Mitcham says: "[He] not only wrote the first monograph on philosophy of technology in English, he has also produced the most extensive corpus devoted to the subject

\footnotetext{
${ }^{13}$ Vielfältigkeit der Technik; Borgmann interpretation of Ihde thesis of philosophy of technology (German translation).
} 
and has established a book series devoted to philosophy of technology" (1994, 78). On the other hand, Mitcham also raises questions about Ihde: "In light of the importance he gives to technology in human experience, his strong sympathies with pragmatism, and his criticisms of the critics of technology, ...it is not clear to what extent his phenomenological philosophy of technology is truly other than a sophisticated and subtle engineering philosophy of technology" -- as opposed to the "humanities philosophy of technology" that Mitcham favors.

Don Ihde ${ }^{14}$ writes, “Technology can no longer be taken for granted. Its impact on and implications for the social, ethical, political, and cultural dimensions of our world must be considered and addressed.

\section{IV}

From a hermeneutical perspective, Ihde characterizes the "existential import" of technologies in terms of "world reflexivity," which he describes as follows: "Humans interpret their world in terms of some focused interpretation. . . . But because humans are also existentially and necessarily related to what they perceive as their world, they 'bring it close' so that ultimately they also interpret themselves in terms of their world" (Ihde, 1979, p. 64). As a consequence of world reflexivity, a notion that Ihde later expands (Ihde, 1983) ,and because computing technology becomes prominent in many activities, humans tend to interpret themselves in terms of this technology, leading to notions such as "the brain is a computer," and "human intelligence can be simulated by computing machines." Thus, a noticeable effect of this technology is that through processes of self-interpretation and world-reflexivity it affects the views that human users of technology have of themselves and of the world.

\footnotetext{
${ }^{14}$ Philosophy of Technology: An Introduction, Don Ihde (1979).
} 
Can we say something more about the relation that constitutes technology? Perhaps we can use some ideas of the American philosopher of technology, Don Ihde, who has read Martin Heidegger as a scholar of phenomenology and who is also under the influence of pragmatism (Ihde, 1979 and 1983). In his book, Technology and the Lifeworld (1990), he focuses on human-technology relations and the cultural embeddedness of technologies. Following a relativistic ontology he draws a distinction between the "direct bodily and perceptual experiences of others and the immediate environment" and "technologically mediated experiences" (Ihde, 1990, pp. 15 ff.). And he suggests as I proposed above that we look for different degrees of mediation in our technologically textured world. The position that conceives of technology as instruments to transform something can be blamed as a Cartesian and subjectivist bias. It is supposed that a self or a subject can use a thing as an instrument to effect something in the outer world. But is it reasonable to speak of a subject, if the technological instruments change the status of subjectivity? Who is the subject in an atomic plant? The clear-cut limits between subject and object become disturbed. "Technics is a symbiosis of artefact and user within a human action" (Ihde, 1990, p. 73). The material relation between humans and the world should be conceived as a symbiotic and mediated relation instead of as a divided and instrumental one.

The late twentieth century seems marked by a deep intellectual discomfort about the ways in which Western thought generally has framed its ways of understanding the World. One symptom of this disease revolves around the current philosophical debates which see either a dramatic end to, or a winding down from 'modernity.' Are we 'postmodern'? 'a-modern'? or, were we, as Bruno Latour claims, never modern to begin with? (Expanding Hermeneutics by Don Ihde, NUP, 1998)

Instrumental Realism has three principal aims: to advocate a "praxisperception" approach to the philosophy of science; to explore ways in 
which such an approach offers a mutually illuminating overlap with a philosophy of technology; and to examine comparatively and critically the work of some who advocate an "instrumental realist" approach to the philosophy of science.

Experimental Phenomenology has already been lauded for the ease with which its author explains and demonstrates the kinds of consciousness by which we come to know the structure of objects and the structure of consciousness itself. The format of the book follows the progression of a number of thought experiments which mark out the procedures and directions of phenomenological inquiry. Making use of examples of familiar optical illusions and multi-stable d drawings, Professor Ihde illustrates by way of careful and disciplined step-by-step analyses, how some of the main methodological procedures and epistemological concepts of phenomenology assume concrete relevance. Such formidable fare as epoche, noetic and noematic analysis, apodicticity, adequacy, sedimentation, imaginative variation, field, and fringe are rendered into the currency of familiar examples from the everyday world.

In his Technics and Praxis Don Ihde explicitly emphasized the necessity of a social embedding of technology and science, as Hans Lenk ${ }^{15}$ and Günter Rophol ${ }^{16}$ did independently in the seventies including what Ihde calls (social) "praxis" as well as a new interpretation. Ihde did more comprehensively emphasize the technological embodiment of science in a literal sense, not only but notably also in "its instrumentation" seeing "a crucial difference" between modern and ancient science (Ihde: 1979, 1991). Ihde epitomizes "the focal point at which instrumental realism emerges" as being "the simultaneous recognition of what I have called the technological embodiment of science, which occurs through the instruments and within experimental situations; and of the larger role of praxis and perception through such technologies" $(1991,99)$.

\footnotetext{
${ }^{15}$ Zur Sozialphilosophie der Technik, Frankfurt a.M. 1982: Suhrkamp.

${ }^{16}$ mit Hans Lenk (Hrsg.) Technik und Ethik, Stuttgart, 1987, 1989: Reclam.
} 
Ihde's Technics and Praxis is an introduction to the phenomenology of instrumentation. The essays assembled in the book deals with technology from a phenomenological perspective. Ihde provides many examples of the application of phenomenological analysis to sample tools (e.g. chalk, telephone, telescope, etc.) of technology, which could be important for the students, studying physics under philosophy of science. At issues is the relation between the human using tools, and either the tools themselves as they present the world (known as "hermeneutic relations") or the world itself as it is experienced through the tools (known as "embodiment relations"). Ihde diagrams these two situations respectively, as:

Human -> (machine -> World) and (Human-> machine) -> World.

How, Ihde ask, do the tools of technology transform human experience? This, it seems to me, is a central question linking physics or any other natural science to the social sciences and humanities. How does science transform experience in our everyday life? Ihde has more precisely expanded the above thesis of human experience with tools in everyday life as four relations in his Technology and Lifeworld book. Ihde argues in A Phenomenology of Technics excerpted from Technology and Lifeworld: From Garden to Earth, that human life has always been suffused with technology. Ihde makes no sweeping claims about technology as such. Instead, Ihde provides a perspective and framework to analyse our experience of technology. The method of analysis is phenomenology, a descriptive method premised on the idea that experience is always relational. The "intentionality of consciousness" of which Ihde writes means that every instance of experience has its reference or direction toward what it is experienced. The aim of phenomenological description is to identify the essential or invariant features of experienced phenomena. Ihde undertakes a phenomenological description of several sets of human-technology relations in order to analyze how technologies often mediate and 
transform our experiences. A phenomenology of human-technology relations shows that the structural dimensions of technological mediation produce a range of possible experiences.

According to Ihde, when we consider the ways our everyday experience is mediated by technological objects, we find several unique sets of human-technology relations, each positioning us in a slightly different relation to technology. One set of relations Ihde calls "embodiment relations" with devices we use to experience the everyday lifeworld and that, at the same time, alter and modify our perception of the world. (Devices, for examples glasses, hearing aids, writing implements, and the handheld tools.) Another set of Ihde calls "hermeneutic relations" that involve instruments that we read rather than use tools. (Devices, for examples clocks, thermometer, spectrographic devices, and other technologies with visual displays, which must be interpreted to be understood.) A third set is "alterity relations", in which technologies appear as "other" to us, possessing a kind of independence from humans as creators and users. (These devices includes things like toys, robots, ATM machine, computer games and visual technologies that we interact with as if they are autonomous beings.) The final fourth set is "background relations," in which technologies form the context of experience in a way that is seldom consciously perceived. (This set of devices includes, for examples the lighting, air conditioning, clothing, shelter, and automatic machines that operate in the background subtly affecting our everyday experience.

With Existential Technics, Don Ihde advances his reflections on the role technology plays in human life. Heretofore primarily the province of Continental thinkers, philosophy of technology is a growing preoccupation of North American philosophers. This collection of essays is a philosophical reflection on and critique of human experience from a clearly American perspective guided by phenomenological analysis. This book is divided into three parts. The first, technics, deals with human interaction with technology and its existential effects. The 
remaining sections on perception and interpretation examine the imaginative use of phenomenology in the visual and auditory realms of art, music, and intercultural perceptions, and are followed by discussions of contemporary hermeneutics and deconstruction theory, particularly in the thought of Heidegger and Derrida.

The pervasive influence of technology in life is analysed by Professor Borgmann from a philosophical, social, historical, political, economic and scientific perspective and reflects the way we have taken up with the world both individually and collectively; such as by considering the nature of contemporary life in the light of technology, the extent to which technology has influenced it and the limitations to the extent technology can provide for human fulfilment. After analysing Albert Borgmann asks a question from their readers, as Can we rekindle an interest in technology's promise?

Technologies up until this time have been used as supplemental tools to the classroom. In this respect they are an added expense to regular classroom activities that becomes difficult to justify in cost accounting. How then can we say that networking and computers will change learning and teaching? Are they just another fad that will fade away like the other learning technologies? New digital technologies have the potential for being very different because they merge all of the previous resources into one accessible unit.

-- The new technologies can provide real world simulations.

-- Learning modules can be accessed at anytime and from any place.

-- Virtual teams of learners can work together to solve problems.

-- Effectively designed programs can provide immediate assessment and evaluation to the learner. 
-- Learners can work on real world problems and have access to experts.

-- New technologies can provide voice-activated dialogues between the learner and the computer.

What problems does technology pose? Albert Borgmann argues that technology is not a neutral tool, as is often assumed in modern liberal democracies furthermore "...it is an equivocation to speak indifferently of tools in a modern and in a pre-technological setting. A means in a traditional culture is never mere but always and inextricably woven into a context of ends." On, what is the character of technology? Borgmann presents a contrast between the device paradigm versus the focal object. A device controls and produces a commodity while reducing itself and its presence to a bare minimum. Examples Borgmann offers are a thermostat, which gives free access to heat but is entirely removed from the production of heat. A fireplace, by contrast, which requires a lot of work, and takes some time, to produce warmth, is a focal thing. (Borgmann, Albert. Technology and the Character of Contemporary Life; A Philosophical Inquiry. Chicago: University of Chicago Press. 1984.)

"Technology and the Good Life?" by Eric Higgs and Andrew Light (A Festschrift on Albert Borgmann) is satisfying in several ways on philosophy and technology. It is focused enough to promote real understanding of its subject and is urgent enough, in its intense desire to help to understand the idiosyncrasies in a "so-called" better post-modern world. In particular, it is a celebration, a critique, and an extension of the philosophy of Albert Borgmann, a German-born, neo-Heideggerian visionary who has taught and published for many years at the University of Montana. Borgmann offers the term, "device paradigm", in his philosophical work, is profoundly important to understand our technological world, to shape its social consequences, to mediate its impact on nature, and to issue its challenge (and tension) to "the good 
life" of the book's title. Borgmann's philosophy can be helpful both for living with technological devices and for understanding the nature of life in a technological age.

Just as books changed the way we stored and retrieved information and enabled us to invent the modern schoolhouse, Internet will change the way we think of learning and teaching. Digital technologies will change the way we store, use and retrieve information. It is because of these changes that digital technologies are very different from others in education. However, I would take caution against thinking that the technology alone will bring about the change. The technology only allows us to think of new ways of learning. Just as books require good authors, the new technology will require new kinds of learning design engineers. Professionals will evolve who can take the research from learning theories and blend it with the technologies. It is not a simple or inexpensive task, but we already see some glimpses of what the future may bring.

Individualized Learner's Plans

Technology allows teachers to have an Individual Learner's Plan (ILP) for every learner that includes medical, social, psychometric, academic achievement and other relevant records. Based upon these records each learner will have an individualized educational plan. Each child will have a weekly update of how they are achieving their goals and objectives. ILPs and records can be given to students on Smart Cards that enable them to have their records and use them when they transfer from school to school.

$\underline{\text { Classroom Goals and Objectives }}$

Each class can have a Website that details the overall goals and objectives for the class. It will have relevant weekly information about 
class activities and objectives. It will have a parent section that discusses the relevance of the goals and objectives for each week. The site will have examples of problem-based educational solutions for class teams working towards specific objectives.

$\underline{\text { Student Assessment and Evaluations }}$

For each child there will be a portfolio assessment file that provides examples of individual work and team work that the student is doing in order to meet the goals and objectives of their Individual Learning Plan. If a learner is falling below expectation of his or her individual learning plan, parents will be alerted within one week of the status of their child.

\section{$\underline{\text { Electronic Management and Support for Teachers }}$}

Teachers today are among the most isolated professionals in the workforce. An electronic Teacher's Associate could provide 1) relevant grade-level national and state standards in a relational database that equates standards and resources, 2) online chat activities with comparable teachers, 3) online access to master teacher mentors, and 4) access to content specialists. Such resources must be made available to every teacher at his or her desk. By 2020 or sooner the Teacher's Associate can bring digital library materials to the teacher's desk. Moreover, desktop publishing can be done at the building or classroom level. Individualized textbooks can be made for each student as needed.

\section{$\underline{\text { Too Much of a Good Thing? }}$}

Since knowledge has expanded, is learning and school just too hard for children to master high academic standards? No, we have always had more knowledge than a single person could master. So the extent of knowledge is not the problem with learners and teachers. It is however more difficult to agree on what the core curriculum should be. 
The system described would be as a support infrastructure for the accomplishment of extrinsic objectives but nonetheless one that may enrich a school \& education system. Individualised Learning Plans felt to me as a means of supporting and monitoring your achievement of the objectives of the school system. Informal Learning Projects (another ILP ironically) can be seen as intrinsic concerns conceptualised into a project and developed as the learner sees fit or as the developmental opportunities may direct. It's a control and a content issue perhaps.

The two ILPs in some senses are not mutually exclusive in that one could relate to the other or even become the other. Sometimes one approach is more contextually appropriate than another. Certainly access to mentors features in both doesn't it? Both recognise the value of dialogue as a sense-making activity and both recognise the benefit of flexibility within the mentoring process.

It would be essential to raise some question marks over the criteria set down for defining innovation. To me they felt more teachers driven and more product- oriented in a context of lifelong learning. Again these questions may be contextually appropriate in certain settings. Having critiqued those questions I'm challenged to construct alternative questions for more open settings.

If learning and teaching are different from the past, what are the characteristics of that difference? For the past decade or so American educators have been asking to define the national standards for content areas. Some would like to return to a classical education suitable for the 1890s and others echo the progressive education movement started in the 1970s. There are conditions today that enter into the general society that our decisions must consider. Information is accessible in many more places today. Radio, television, cable television, recorded materials, Internet and the telephone are available for learners of all ages. Learning 
happens in places outside the school, such as in the home, church, library, museum and little league parks.

The digital world has blurred the walls of the schools and places of learning. Individual learners can learn anywhere anytime and at their own pace. We have always had some children that use broad community resources, but the ease of doing it today is greater than ever. Technology extends our communications ability beyond face-to-face talking. It expands it beyond the printed page and reading to a new dimension. It is building a new and more efficient means of sharing ideas and information among all people.

\section{References (Cited and Non-cited)}

Borgmann, Albert. "Orientation in Technology," Philosophy Today 16 (1972): 135-47.

Bprgmann, Albert. "Functionalism in Science and Technology," Proceedings of the XVth World Congress of Philosophy (Sofia: Sofia Press Production Centre, 1973-75), 2: 31-36.

Borgmann, Albert. "The Explanation of Technology," Research in Philosophy and Technology 1 (1978): 99-118.

Borgmann, Albert. "Technology and Nature in Europe and America," International Dimensions of the Environmental Crisis, ed. Richard N. Barrett (Boulder, CO: Westview, 1982) 3-20.

Borgmann, Albert. "The Good Life and Appropriate Technology," Research in Philosophy and Technology 6 (1983): 11-19. To be reprinted in Technology: Assessments and Alternatives, ed. Frederick Ferré (Herbert Johnson Publisher). 
Borgmann, Albert. "Philosophical Reflections on the Microelectronic Revolution," in Philosophy and Technology II, ed. Carl Mitcham and Alois Huning, Boston Studies in the Philosophy of Science (Dordrecht: Reidel, 1986) 189-203. German version in Technikphilosophie im Zeitalter der Informationstechnik, ed. Mitcham and Huning (Braunschweig, Germany: Vieweg, 1986) 143-54.

Borgmann, Albert. "The Invisibility of Contemporary Culture," Revue internationale de philosophie 41 (1987): 234-49. Referenced in Sociological Abstracts.

Borgmann, Albert. "Reply" Technology and Contemporary Life, ed. Paul T. Durbin (Dordrecht: Reidel, 1988) 29-43. (This is the response to reviews by Professors Stanley Carpenter and Manfred Stanley, presented at a symposium of the American Philosophical Association on my Technology and the Character of Contemporary Life. The reviews are published in the same volume.)

Borgmann, Albert. "The Moral Significance of the Material Culture," Inquiry 35 (1992): 291-300, reprinted in Technology and the Politics of Knowledge, ed. Andrew Feenberg and Alastair Hannay (Bloomington, IN: Indiana University Press, 1995) 85-93.

Borgmann, Albert, "Does Philosophy Matter?" Technology in Society 17 (1995): 295-309.

Borgmann, Albert. "The Meaning of Technology," The World and I, March 1996: 289-99.

Borgmann, Albert. "Reply to My Critics," Technology and the Good Life?, ed. Eric Higgs, Andrew Light, and David Strong (Chicago: University of Chicago Press, 2000), pp. 341-70. 
Borgmann, Albert. "Information, Nearness, and Farness," The Robot in the Garden, ed. Ken Goldber (Cambridge, MA: MIT Press, 2000), pp. 92-107.

Borgmann, Albert. "Semiartificial Intelligence," Heidegger, Coping, and Cognitive Science, ed. Mark Wrathall and Jeff Malpas (Cambridge: MIT Press, 2000), pp. 197-205 and 369.

Borgmann, Albert. "Heidegger and Ethics Beyond the Call of Duty," Appropriating Heidegger, ed. Mark Wrathall and James Faulconer (Cambridge: Cambridge University Press, 2000), pp. 68-81.

Borgmann, Albert. "On the Blessings of Calamity and the Burdens of Good Fortune," Hedgehog Review 4 (2002), pp. 7-24

Borgmann, Albert. "Response to My Readers," Techne: Journal of the Society for Philosophy and Technology 6 (2002), available at http://scholar.lib.vt.edu/ejournals/SPT/v6n1/ August 13, 2003.

Borgmann, Albert. "Kinds of Pragmatism", Techne: Journal of the Society for Philosophy and Technology 7 Spring 2003, Special Issue: Larry Hickman's Philosophical Tools for Technological Culture http://scholar.lib.vt.edu/ejournals/SPT/v7n1/borgmann.html October 27, 2003

Borgmann, Albert. Technology and the Character of Contemporary Life: A Philosophical Inquiry. Chicago: University of Chicago Press, 1984; 5th printing 1997.

Borgmann, Albert. Crossing the Postmodern Divide. Chicago: University of Chicago Press, 1992; 5th printing 1998. Chinese translation 2003. 
Borgmann, Albert. Holding On to Reality: The Nature of Information at the Turn of the Millennium. Chicago: University of Chicago Press, 1999.

Ihde, Don. EXISTENTIAL TECHNICS ( SUNY Press, 1983).

Ihde, Don. TECHNOLOGY AND THE LIFEWORLD: FROM GARDEN TO EARTH (Indiana University Press, 1900).

Ihde, Don. INSTRUMENTAL REALISM: THE INTERFACE BETWEEN PHILOSOPHY

OF TECHNOLOGY AND PHILOSOPHY OF SCIENCE (Indiana University Press, 1991).

Ihde, Don. PHILOSOPHY OF TECHNOLOGY: AN INTRODUCTION (Paragon House, 1993).

Ihde, Don. POSTPHENOMENOLOGY: ESSAYS IN THE POSTMODERN CONTEXT (Northwestern University Press, 1993).

Ubiquity -- Volume 7, Issue 23

$<$ http://www.acm.org/ubiquity/> 